\title{
THE IMPORTANCE OF KNOWLEDGE MANAGEMENT IN THE PROCESS OF BRAND EQUITY
}

\author{
Tina Vukasović ${ }^{1}$ (D)
}

DOI: https://doi.org/10.31410/LIMEN.S.P.2019.1

\begin{abstract}
The potential to provide customers with information about experience and credence qualities in advance of purchase has resulted in widespread recognition of the significance of brands in relation to consumer choice. The paper's contribution is to present the importance of knowledge management in the process of creating brand equity in selected companies. A strong and trusted brand provides the company with competitive advantage and in order to achieve it, employee knowledge is required. The quantitative research method and a structured questionnaire were used for collecting research data. Online survey was used as the method of data collection. The research sample comprised 200 respondents, of whom i.e. company employees in selected companies. The distinctive contribution of this research arises from the examination of brand equity in the context of an emerging market in selected companies. This paper investigates the role of knowledge management in the process of creating brand equity.
\end{abstract}

Keywords: Brand, Brand equity, Knowledge management, Small and medium-sized enterprises, Slovenia.

\section{INTRODUCTION}

$\mathrm{O}$ ver the past two decades in particular, marketing research and marketing practice have paid increasing attention to the processes associated with building a strong relationship between brand and consumer and it is often argued that the brand is the most valuable asset for any company (Aaker, 1991a, b, 2003; Kapferer, 1997; Blackett, 1993). The concept of brand equity is of particular relevance to consumer choice. In essence, brand equity measures the value of the brand, both to the organization and to the consumer. For the consumer, this added value arises from the brand's role as an indicator of desirable attributes and as the basis for building an emotional bond (Teas and Grapentine, 1996; Mourad et al., 2010). Brand equity is a key concept for marketing academics and one of the most prized assets for firms (Ambler, 2003; Christodoulides and de Chernatony, 2010; Christodoulides et al., 2015).

Brands are quickly becoming a common subject of deliberation and discussion in business. They are an important part of a company's assets and must be correctly managed and valued. Companies are becoming increasingly aware that the higher the brand equity, the greater the company's competitiveness and the higher the achieved market price of products or services (Vukasović, 2016). A successful brand brings the company recognition with buyers, suppliers, shareholders, banks, and other external stakeholders. In order to achieve this objective, the company requires specific types of knowledge which is used in the company and transferred to business processes. We must see to increasing or at least maintaining brand equity, as brands can rightly be classified as part of a company's assets. Strong and established brands differentiate the company from the products or services offered by the competition (Vukasović, In press). 
Modern marketing theory and practices have recognized the brand equity paradigm as a key strategic asset for organizations. Keller and Lehmann (2006) have argued that a brand is influential or manifests its importance at three key levels which correspond to three distinct yet interconnected market dimensions, or indeed three distinct markets: customer, product and financial markets. Thus, value accrued by these markets may be designated as brand equity. The brand equity paradigm has been discussed extensively in marketing literature and many researchers have offered a wide array of definitions for the brand equity concept (Aaker, 1991; Farquhar, 1989; Sriram et al., 2007; Christodoulides and de Chernatony, 2010; Davcik et al. 2015), as well as different perspectives on the factors that influence brand equity.

Today, knowledge is a fundamental value. An increasing number of companies are therefore coming to the awareness that sufficient knowledge is needed for their survival and success. Knowledge is a justified true belief which is perceived as a dynamic human process of justifying personal belief toward the truth. There are two types of knowledge; implicit or tacit knowledge, which is personal knowledge of which we are often unaware and explicit knowledge or knowledge in companies, which is formal and systematic (Nonaka and Takeuchi, 1995, p. 58). Both types of knowledge affect brand management as one of the most important marketing tools. Our study focuses on both types of knowledge that play a part in the brand management process and the process of creating brand equity. If companies want to be successful, knowledge management must include all knowledge processes, i.e. knowledge discovery and acquisition, knowledge transfer, and knowledge application. From the organisation's point of view, knowledge management is exceptionally important, as it enables brand equity, as part of the company's assets, not to be decreased but maintained or even increased (Vukasović, In press).

Even though literature on knowledge management is extensive, little attention is paid to studying the importance or role that knowledge management plays in the process of creating brand equity. Authors (Keller, 1993; Aaker, 1996; Grønhaug et al., 2002; Yoo and Donthu, 2002; Gibbert et al., 2002; Pappu et al., 2006; Anselmsson, 2014; Vukasović, 2016, and others) often study only the importance of consumer knowledge of the brand and its value and not the importance of knowledge in the company for brand equity. Richards et al. (1998, p. 47) argue that it is surprising that the marketing function in so many companies has done so little to advance the management of value-adding activities, i.e. brand knowledge. It is our intent, therefore, to establish which knowledge the studied small and medium-sized enterprises (SMEs) use to achieve brand equity (Vukasović, In press).

The main research problem is to analyse the importance of knowledge management in the process of creating brand equity in the SMEs. Companies can maintain their competitive advantage only with high-value brands. In order to create high-value brands, knowledge is needed within the company. The objective of the study is to establish the importance of different types of knowledge in the process of creating brand equity and to provide key findings and proposals on the role of knowledge in creating brand equity. The distinctive contribution of this research arises from the examination of brand equity in the context of an emerging market in SMEs. The paper's contribution is to present the role of implicit and explicit knowledge in the process of creating brand equity in the SMEs. 


\section{RESEARCH DESIGN}

\subsection{Methodology and sample}

The quantitative research method and a structured questionnaire with different sets of questions were used for collecting research data. The research design was designed according to the questionnaire in research of the author Vukasović (In press). The survey took place in a in SMEs in Slovenia. Online survey was used as the method of data collection. We have distributed the online survey to Facebook groups for those interested in entrepreneurship (Female Entrepreneurship, Slovenian Entrepreneurship, Marketing Academy). These are companies that promote entrepreneurship, have large business databases and have sent them a survey link by email (more than 16,000 emailing addresses in total).

We have decided to survey SMEs, regardless of their geographical location (all of Slovenia). The criterion used to determine the size of the company was the number of employees in the company. A small enterprise is an enterprise with up to 50 employees and a medium enterprise is an enterprise with up to 250 employees.

The research sample comprised 200 respondents. Malhotra (1999) suggested minimum sample of problem solving is at least 200 samples. Thus, we have used the recommendations of Malhotra (1999), which are at least 200 samples. A simple random sample was chosen. To complete the survey, we asked sole proprietors, managing directors, entrepreneurs and founders, office/ department managers who have an overview of the situation and development in the company, product managers, project managers, marketing managers or marketing staff. The survey used the improbability sampling technique - self-selection and quota sampling; we planned a quota of $75 \%$ of small enterprises and $25 \%$ of medium enterprises; we achieved a quota of $20 \%$ of medium enterprises and $80 \%$ of small enterprises. The collected data were analysed and processed with SPSS. The share of respondents in the age group from 36 to 40 years is the highest and represents $52 \%$. The age group from 25 to 30 years represents $18 \%$. The age group above 46 represents $12 \%$. The age group from 31 to 35 years represents $10 \%$ and the age group from 41 to 45 years with the lowest percentage of $8 \%$.

Asked which level of educational attainment prevails among the employees managing brands, the majority of the 200 responded answered that these were people with higher education, i.e. $58.6 \%$, followed by employees with university education $(25.2 \%)$, secondary education $(12.6 \%)$, and a negligible share of those with postgraduate education $(2.9 \%)$ and primary education $(0.7 \%)$. This allows us to conclude that brand management in SMEs is in the hands of educated staff, which indirectly indicates that companies attribute importance to knowledge when it comes to brand management.

\section{RESULTS AND DISCUSSION}

This part of the analysis of the study is the basic descriptive statistical analysis whose results are presented below. The next question focused on the respondents' opinions on the formal knowledge of employees who are included in brand management in the company. The respondents assessed a set of statements on a scale of 1 to 5, with 1 meaning "I completely disagree" and 5 "I completely agree". The results are shown in Table 1. 
Table 1 shows that the respondents mainly agreed with the majority of the statements, as only one assessment has a value of less than 3 , while all others are higher and indicate agreement. The highest level of agreement (3.92) was achieved by the statement that the employees have the appropriate level of education for the job. For this statement, standard deviation is also relatively low, which indicates uniformity of answers. A high level of agreement (3.71) was also achieved by the statement that the employees' knowledge of brand management is satisfactory. The lowest level of agreement (2.72) was achieved by the statement that only employees with appropriate formal knowledge are promoted in the company.

Table 1. Respondents' opinions on the formal knowledge of employees who are included in brand management

\begin{tabular}{|c|c|c|c|}
\hline Statement & $\mathbf{M}$ & SD & n \\
\hline The employees have the appropriate level of education for the job. & 3.92 & .643 & 200 \\
\hline $\begin{array}{l}\text { The employees use the documented knowledge to gain new } \\
\text { knowledge and create brand equity. }\end{array}$ & 3.86 & .891 & 200 \\
\hline $\begin{array}{l}\text { Brand management knowledge is kept in manuals, books, } \\
\text { documents. }\end{array}$ & 3.75 & .894 & 200 \\
\hline The employees' knowledge of brand management is satisfactory. & 3.71 & .876 & 200 \\
\hline The employees' knowledge of marketing is satisfactory. & 3.65 & .967 & 200 \\
\hline $\begin{array}{l}\text { Only employees with appropriate formal knowledge are promoted in } \\
\text { the company. }\end{array}$ & 2.72 & .986 & 200 \\
\hline
\end{tabular}

Note: $\mathrm{M}$ - mean, $\mathrm{SD}$ - standard deviation, $\mathrm{n}$ - number of answers

The next set of statements refers to the application of knowledge. The respondents assessed the statements on a scale of 1 to 5, with 1 meaning "I completely disagree" and 5 "I completely agree".

Table 2 shows that the respondents relatively uniformly agreed with all the statements. The highest level of agreement (4.75) was achieved by the statement that the management rewards the best proposals and ideas. For this statement, standard deviation is also relatively low, which indicates uniformity of answers. Indecisiveness was evident with the second and third statement. The agreement that the management rewards employees for successfully applied new knowledge with financial incentives slightly prevailed (0.05) over the agreement with the statement that it rewards them with non-financial incentives.

Table 2. Application of knowledge

\begin{tabular}{|l|c|c|c|c|}
\hline Statement & N & M & SD & n \\
\hline The management rewards the best proposals and ideas. & 80 & 4.75 & .669 & 200 \\
\hline The management rewards employees for successfully applied new & & & & \\
knowledge - financial incentives. & 81 & 4.23 & .866 & 200 \\
The management rewards employees for successfully applied new & 81 & 4.18 & .895 & 200 \\
knowledge - non-financial incentives. & & & & \\
\hline
\end{tabular}

Note: $\mathrm{M}$ - mean, $\mathrm{SD}$ - standard deviation, $\mathrm{n}$ - number of answers

The next set of statements refers to the possibility of acquiring knowledge. The results are shown in Table 3. The respondents assessed the statements on a scale of 1 to 5, with 1 meaning "I completely disagree" and 5 "I completely agree".

Table 3 shows that the highest level of agreement (4.66) was achieved by the statement that the management invests extensively in brand management training. For this statement, standard deviation is also relatively low, which indicates uniformity of answers. A high level of agreement was also achieved by the statements that the company's current vision and policy support 
the process of learning and knowledge development (4.38) and that the management encourages and supports employees in further education (4.33). The lowest level of agreement (3.62) was achieved by the statement that the employees read specialised literature.

Table 3. Acquiring knowledge - training

\begin{tabular}{|l|c|c|c|}
\hline Statement & M & SD & n \\
\hline The management invests extensively in brand management training. & 4.66 & .648 & 200 \\
\hline $\begin{array}{l}\text { The company's current vision and policy support the process of } \\
\text { learning and knowledge development. }\end{array}$ & 4.38 & .765 & 200 \\
\hline $\begin{array}{l}\text { The management encourages and supports employees in further } \\
\text { education. }\end{array}$ & 4.33 & .656 & 200 \\
\hline The management encourages part-time study. & 4.12 & .678 & 200 \\
\hline $\begin{array}{l}\text { The employees acquire the majority of the knowledge within the } \\
\text { company through internal training, teamwork, etc. }\end{array}$ & 4.05 & .745 & 200 \\
\hline The management is aware that it must invest in employee training. & 4.01 & .781 & 200 \\
\hline The employees express the desire and need to learn. & 3.82 & .765 & 200 \\
\hline The employees read specialised literature. & 3.62 & .821 & 200 \\
\hline
\end{tabular}

Note: $\mathrm{M}$ - mean, $\mathrm{SD}$ - standard deviation, $\mathrm{n}$ - number of answers

The next set of the statements refers to the possibility of acquiring knowledge from the competition. The results are shown in Table 4. The respondents assessed the statements on a scale of 1 to 5, with 1 meaning "I completely disagree" and 5 "I completely agree".

Table 4 shows that the highest level of agreement (4.31) was achieved by the statement that the employees systematically monitor and acquire new knowledge from the competition, suppliers, and customers. For this statement, standard deviation is also relatively low, which indicates uniformity of answers. A high level of agreement (4.24) was also achieved by the statement that the knowledge acquired from customers and suppliers provides the company with comparative advantage and differentiation from the competition. For this statement, standard deviation is again relatively low, which indicates uniformity of answers. A relatively high level of agreement (3.96) was achieved by the statement that the employees use benchmarking (learning from the best competitors) to acquire new knowledge. The lowest level of agreement (2.95) was achieved by the statement that new knowledge is acquired by buying licences and patents.

Table 4. Acquiring knowledge from the competition

\begin{tabular}{|c|c|c|c|}
\hline Statement & M & SD & n \\
\hline $\begin{array}{l}\text { The employees systematically monitor and acquire new knowledge } \\
\text { from the competition, suppliers, and customers. }\end{array}$ & 4.31 & .652 & 200 \\
\hline $\begin{array}{l}\text { The knowledge acquired from customers and suppliers provides the } \\
\text { company with comparative advantage and differentiation from the } \\
\text { competition. }\end{array}$ & 4.24 & .656 & 200 \\
\hline $\begin{array}{l}\text { The employees use benchmarking (learning from the best } \\
\text { competitors) to acquire new knowledge. }\end{array}$ & 3.96 & .781 & 200 \\
\hline $\begin{array}{l}\text { The employees acquire new knowledge by setting up a joint venture } \\
\text { with those who already have the required knowledge. }\end{array}$ & 3.45 & .993 & 200 \\
\hline $\begin{array}{l}\text { The management buys licences and patents to acquire new } \\
\text { knowledge. }\end{array}$ & 2.95 & .896 & 200 \\
\hline
\end{tabular}

Note: $\mathrm{M}$ - mean, $\mathrm{SD}$ - standard deviation, $\mathrm{n}$ - number of answers

The next set of statements refers to the types of knowledge transfer. The results are shown in Table 5. The respondents assessed the statements on a scale of 1 to 5, with 1 meaning "I completely disagree" and 5 "I completely agree". 
Table 5 shows that the highest level of agreement (4.63) was achieved by the statement that the employees help each other with advice. For this statement, standard deviation is also relatively low, which indicates uniformity of answers. A high level of agreement (3.75) was also achieved by the statement that the employees acquire knowledge and experience directly through education and training. The lowest level of agreement (2.95) was achieved by the statement that the employees hide their knowledge from their colleagues, as they believe this increases their competitiveness.

Table 5. Knowledge transfer

\begin{tabular}{|c|c|c|c|}
\hline Statement & M & SD & n \\
\hline The employees help each other with advice. & 4.63 & .685 & 200 \\
\hline $\begin{array}{l}\text { The employees acquire knowledge and experience directly through } \\
\text { education and training. }\end{array}$ & 3.75 & .867 & 200 \\
\hline $\begin{array}{l}\text { The most appropriate type of knowledge transfer in the company are } \\
\text { work meetings. }\end{array}$ & 3.46 & .762 & 200 \\
\hline $\begin{array}{l}\text { The company has established a best practice transfer process among } \\
\text { employees. }\end{array}$ & 3.42 & .915 & 200 \\
\hline $\begin{array}{l}\text { The employees hide their knowledge from their colleagues, as they } \\
\text { believe this increases their competitiveness. }\end{array}$ & 2.95 & .894 & 348 \\
\hline
\end{tabular}

Note: $\mathrm{M}$ - mean, $\mathrm{SD}$ - standard deviation, $\mathrm{n}$ - number of answers

\section{CONCLUSION}

In today's competitive business environment, the concept of brand equity is an important source of strategic intelligence for marketers. Brand equity serves three important roles: (a) it acts as a magnet to attract new customers to the firm, (b) serves as a reminder to the customers about the organisation's products and services, (c) it is customer's emotional tie to the organisation (Lemon et al., 2001). The paper's contribution is to present the importance of knowledge management in the process of creating brand equity. A strong and trusted brand provides the company with competitive advantage and in order to achieve it, employee knowledge is required. In small and medium-sized enterprises, brand management is in the hands of educated staff, which indirectly indicates that the company believes knowledge to be important for brand management. The employees have the appropriate education for brand management; however, they lack branding knowledge. An encouraging finding of this study is that brand management is entrusted to qualified staff, which gives weight and importance to this subject matter.

The selected companies place a lot of importance on training its employees, which contributes to better brand valuation and management. The management invests extensively in brand management training. Current vision and policy support the process of learning and knowledge development and the management encourages and supports employees in further education. In order to receive training on brands, the employees most frequently employ Internet training, while the knowledge acquired from customers and suppliers provides the company with comparative advantage and differentiation from the competition. They are aware that the knowledge acquired from customers and suppliers provides the company with competitive advantage. This is the right direction, as comparative advantages over the competition can be achieved through a synergy of own knowledge and the knowledge of suppliers and customers. They are aware that own and newly acquired knowledge can create new and greater added value for the company. The employees cooperate and exchange knowledge and experiences. 
It can be concluded that the studied small and medium-sized enterprises are aware of the importance of knowledge in the process of creating brand equity. Implicit (informal knowledge, ideas, experience, values, etc.) and explicit knowledge (formal educational attainment, documented knowledge, training, knowledge acquired from customers and suppliers, etc.) play an important role in the process of creating brand equity, which in turn requires knowledge management processes such as discovery, acquisition, exchange, and application of knowledge, which the studied companies implement. The results are comparable to a study by the author Vukasović (In press) in the case of one selected company. Knowledge management opens the door to many opportunities, where management is dealing with knowledge and the role of management in all of these, and an important learning resource is important. The time in which we live demands that decision-makers, who are increasingly influencing the organization as such, demand from the organization's leaders to quickly take decisions, and the management must be aware of the real value of its employees and the knowledge they have. By transferring, maintaining and nurturing knowledge, employees work for the benefit of the organization, and with motivation, the organization's goals become feasible (Vukasović, In press).

A clear limitation is the fact that this study has only small and medium-sized enterprises and one country (Slovenia).

\section{REFERENCES}

Aaker, D. (1991) Managing Brand Equity. New York: The Free Press.

Aaker, D. (2003) The power of the branded differentiator. MIT Sloan Management Review, 45(1), 83-7.

Aaker, D. A. (1996) Measuring brand equity across products and markets. California Management Review, 38(3), 102-120.

Alhalwaki, H. and Mousa Hamdan, A.M. (2019) ,Factors affecting the implementation of internationalisation strategies in higher education institutions: evidence from Bahrain', International Journal of Management in Education, Vol. 13, No. 1, pp. 1 - 27.

Ambler, T. (2003) Marketing and the Bottom Line: Creating the Measures of Success. London: Financial Times/Prentice Hall.

Anselmsson, J., Vestman Bondesson, N., in Johansson, U. (2014) Brand image and customers' willingness to pay a price premium for food brands. Journal of Product \& Brand Management, 23(2), 90-102.

Blackett, T. (1993) Brand and trademark valuation - what's happening now? Marketing \& Research Today, May, 111-13.

Christodoulides, G. and de Chernatony, L. (2010) Consumer-based brand equity conceptualization and measurement: a literature review. International Journal of Market Research, 52(1), 43-66.

Christodoulides, G., Cadogan J. W. and Veloutsou, C. (2015) Consumer-based brand equity measurement: lessons learned from an international study. International Marketing Review, 32(3/4), $307-328$.

Davcik, N. S., da Silva, R. V., and Hair, J. F. (2015) Towards a unified theory of brand equity: conceptualizations, taxonomy and avenues for future research Journal of Product \& Brand Management, 24(1), 3 - 17.

Farquhar, P.H. (1989) Managing brand equity. Marketing Research, 1(3), 24-33.

Gibbert, M., Leibold, M. and Probst, G. (2002) Five Styles of Customer Knowledge Management, and How Smart Companies Use Them to Create Value. European Management Journal, 20(5), 459-469. 
Grønhaug, K., Hem L. and Lines, R. (2002). Exploring the Impact of Product Category Risk and Consumer Knowledge in Brand Extensions. The Journal of Brand Management, 9(6), 463-476.

Kapferer, J.N. (1997) Strategic Brand Management. London: Kogan Page.

Keller, L. K. (1993) Conceptualizing, Measuring and Managing Customer Based Brand Equity. Journal of Marketing, 57, 1-22.

Keller, K. and Lehmann, D. (2003) How Do Brands Create Value. Marketing Management, 12(3), 26-31.

Lemon, K. N., Rust, R. T. and Zeithaml, V. A. (2001) What Drives Customer Equity? Marketing Management, 10(1), 20-25.

Malhotra, N. K. (1999) Marketing Research: An Applied Orientation. New Jersey: Prentice Hall.

Mourad, M. (2010) Internationalisation: a new positioning strategy in the higher education market. International Journal of Management in Education, 4(2), 185-200.

Nonaka, I., and Takeuchi, H. (1995) The Knowledge - Creating Company: How Japanese Companies create the dynamics of innovation. Oxford: Oxford University Press.

Pappu, R., Quester, P. G., and Cooksey, R. W. (2006) Consumer based brand equity and country-of-origin relationships. European Journal of Marketing, 40(5/6), 696-717.

Richards, I., Foster, D. and Morgan, R. (1998) Brand Knowledge Management: Growing Brand Equity. Journal of Knowledge Management, 2(1), 47-54.

Sriram, S., Subramanian, B. and Manohar, U.K. (2007) Monitoring the Dynamics of Brand Equity Using Store-Level Data. Journal of Marketing, 71(2), 61-78.

Teas, K. and Grapentine, T. (1996) Demystifying brand equity. Marketing Research, 8(2), 24-30.

Vukasović, T. (2016) An Empirical Investigation of Brand Equity: A Cross-Country Validation Analysis. Journal of Global Marketing, 29(5), 251-265.

Vukasović T. (In Press) Knowledge as an Important Factor in the Process of Creating Brand Equity. Int. J. Innovation and Learning.

Yoo, B., and Donthu, N. (2002) Testing cross-cultural invariance of brand equity creation process. Journal of Product \& Brand Management, 11(6), 380-398. 